\title{
Learning Space Design and Classroom Behavior
}

\author{
Edward J. Baum \\ Grand Valley State University \\ Allendale, Michigan U.S.A.
}

\begin{abstract}
This report describes a study of the impact of learning space design on student and instructor behavior. We investigated learning space features that enable guided inquiry instruction in two different classrooms, a typical node classroom, and a spoke classroom, the Steelcase Learn Lab. Students report that group cohesiveness, engagement, task orientation, and cooperation are encouraged in both classrooms. Both classrooms are not equally satisfactory for the same types of activity, however. The Spoke classroom best supports and is clearly preferred for group activities such as case studies, discussions, and debates. The seating offers excellent sight lines, enabling everyone in the room to easily interact with everyone else as well as see visual presentations. The seating arrangement in the Node classroom fragments the class into small study/research groups, making it an ideal environment to apply various well-known small-group active learning methods such as "Physics by Inquiry" and "Process-Oriented GuidedInquiry Learning".
\end{abstract}

Keywords: active learning, learning space design, student engagement.

\section{Introduction}

The adoption of active learning methods in post-secondary education creates a demand for teaching spaces designed to accommodate such teaching strategies. Conventional teaching spaces that emphasize the role of the instructor are being replaced by spaces designed to afford students greater opportunity to actively participate in their education (Brown and Lippincott 2003). Classroom design flaws resulting from misunderstanding of how the teaching space will be used is a continuing problem in post-secondary education (Brase, 1988). What design features best support and enhance the educational activities that will, in fact, take place?

The research described here compared the impact of two room arrangements, a typical node classroom and a Steelcase Learn Lab or spoke classroom, on the behavior and attitudes of both student and instructor in an Honors cooperativelearning science course for non-majors. The objective of our study was to assess 
how the design features of each classroom enables or inhibits active learning strategies.

\section{Background}

Early work on the impact of the physical learning environment on student behavior and performance has been reviewed (Weinstein, 1979; Earthman and Lemaster, 1996). Originally, it was commonly assumed that learning was substantially uninfluenced by the physical space in which it took place (Cruickshank and Quay, 1970). Classrooms were designed with little concern for more than adequate heating and lighting. Subsequent research showed that the physical environment of conventional classrooms does affect student behaviors and attitudes (Moore, 1986; Cannon, 1988; Banning, 1992; Conway, 2000; Monahan, 2002; Brooks, 2011). Strange and Banning (2001, p15) asserted that "although features of the physical environment lend themselves theoretically to all possibilities, the layout, location, and arrangement of space and facilities render some behaviors much more likely, and thus more probable, than others." Scott-Webber (2000) reviewed research on how space makes students feel as related to knowledge creation, communication, and application, arguing that space configurations exert powerful influences on such activities. Research involving the teaching of scientific subjects like mathematics, chemistry, and physics suggests that the physical environment should produce measurable changes in student and teacher behavior (Weinstein 1979; AMA 2006).

The physical arrangement of a teaching space can bring people together, encouraging collaboration and discussion, or it can enforce isolation and silence. Environments that promote social collaboration, stimulate the senses, encourage the exchange of information, and offer opportunities for rehearsal, feedback, application, and transfer are likely to support active learning. Also, the availability of instructional technology is a key predictor of student performance (Tanner, 2000; Fisher, 2000; Hurst, 2005).

Much of the research on this subject was done in K-12 settings, and it is widely assumed that the physical classroom environment influences college student behavior and performance, also (Banning, 1992; Tinto, 1997; Scott-Weber et al., 2000). There is supporting evidence for the assumption. The positive impact of learning-space design on conceptual understanding (Dori and Belcher 2004; Syllabus Media Group, 2005), student satisfaction (Hill and Epps, 2009), class attendance rate, class dropout rate, and long-term retention rate (Sommer and Olsen, 1980; Acker and Miller, 2005) have been reported. In comparison with control groups, mathematics and science students exhibited improved ability to solve problems, increased conceptual understanding, and reduced failure rates when taught in collaborative learning environments using specially-designed, technology-enabled learning spaces (Schneider, 2002). Hill and Epps (2009), in a controlled study with accounting students, show that comfortable spaces with good air quality, lighting, seating, and acoustics were effective in elevating student satisfaction and student evaluation of teacher performance. Espey (2008) reports that student attitudes toward team learning are elevated by room 
designs that enhance ease of communication within teams. In one study, students most often reported that physical spaces with seating arrangements that promote group work and interaction and having good sight lines to visuals positively impacted their learning (Veltri, Banning, and Davies, 2006).

Instructors respond favorably to good teaching spaces and adversely to poor ones, too. However, space design alone will not induce instructors to attempt unfamiliar and uncomfortable teaching strategies. Indeed, one report of a study comparing a range of classroom space designs, from traditional row seating to more flexible, non-traditional seating arrangements, states that "faculty who were not comfortable with a range of pedagogical approaches tended to alter the most innovative [teaching] spaces so that the rooms would have a lecture room feel" (Hunley and Schaller, 2009).

There are several issues that confound the study of learning environment impact, and the literature on student performance and learning space design should be viewed with some caution. First, the literature is replete with unsupported anecdotal claims of improved student performance attributed to new classroom design. Apart from this, the learning environment is complex with many features acting together to influence student attitudes and behavior, and it is difficult to replicate learning environments among research studies. Also, some confusion may stem from the great variation in study design as well as in classroom design employed. Finally, it is not always clear how well the classroom design supported the pedagogy chosen for the research study or how well the instructor used the spatial design to support the chosen pedagogy.

Some studies measure student performance related to classroom environment (Dopplet and Barak, 2002; Brooks, 2011; Muthyala, and Wei Wei, 2013), but most measure student attitude to changes in the physical environment and extrapolate the results to student performance. The assumption is made that positive student attitude change must result in positive student performance change. Further, observed change in student behavior and performance may be due to the Hawthorne Effect in which study participant's performance is enhanced as they are aware that they are the subject of investigation.

In view of the foregoing, it is not surprising that some researchers report observing significant impacts of classroom design on student performance, while others find no reliable relationship between performance and physical environment. Prior research involving the teaching of scientific subjects like mathematics, chemistry, and physics, suggests that the physical environment should promote measureable changes in student and teacher behavior, but some researchers report that the changes might not be predictable (Weinstein 1979; AMA 2006).

\section{Experimental}

We conducted a comparative study of the impact of two technology-enhanced, studio-style classrooms, a Steelcase Spoke classroom and a Node classroom, on 
both student and instructor attitude and behavior in an Honors science course for non-majors. The class was held in alternate learning spaces during successive class sessions. The experimental design is similar to earlier studies comparing active-0learning classrooms with conventional lecture classrooms. (Brooks, 2012)

Methods for assessing the design of teaching spaces have been discussed (Sanoff, 1994; Sanoff, 2000; Dopplet and Schunn, 2008). Our research design was similar to that of earlier studies of learning environment and student satisfaction (Zandvleit and Fraser, 2004) as well as to that of studies of workplace ergonomics factors that influence worker health and productivity (Kroemer and Grandjean, 1997).

Setting and Participants: The two learning spaces are approximately equal in size, roughly 900 square feet. They differ in seating arrangement, lighting, audio-visual equipment, and computing equipment. Diagrams of the rooms are given in Figure 1. The node classroom is a typical studio classroom designed to support a range of activities. Students are seated around six tables, four to a table, arranged in two rows of three tables. The seats and tables are moveable. The instructor's stage and all audio-visual resources and computing equipment are located prominently in the front of the room. Large white boards are located in the front and along the side walls of the space. Long tables are located along the side walls and can be used for laboratory experiments. The instructor is able to easily move around the room interacting with students. The room is comfortable with plenty of natural lighting.

The Steelcase spoke classroom furniture arrangement, seating density, sight lines, and advanced communication technology promote student interaction and communication. Students are grouped around five large tables, six to a table, arranged as spokes of a wheel. There is no front of the room and no back row. Projection screens are located at two corners and along one wall of the room. White boards are located on two opposite walls. An audio-visual control center is located in one corner of the room, but most display systems can be controlled with a mobile, hand-held device. The room also features a smart board and small portable white boards, huddle boards, for display of group work. Notes written on the large white boards and on the huddle boards can be photographed with cameras located on two sides of the room and posted to the course web site. Each table has network connections for laptop computers, and student groups can control the room's audio-visual devices from their posts to make presentations to the class. There is no convenient place from which to lecture, and the instructor is encouraged to move about the room and interact directly with the students. The room is comfortable, but it is not as well lit as the node classroom. 


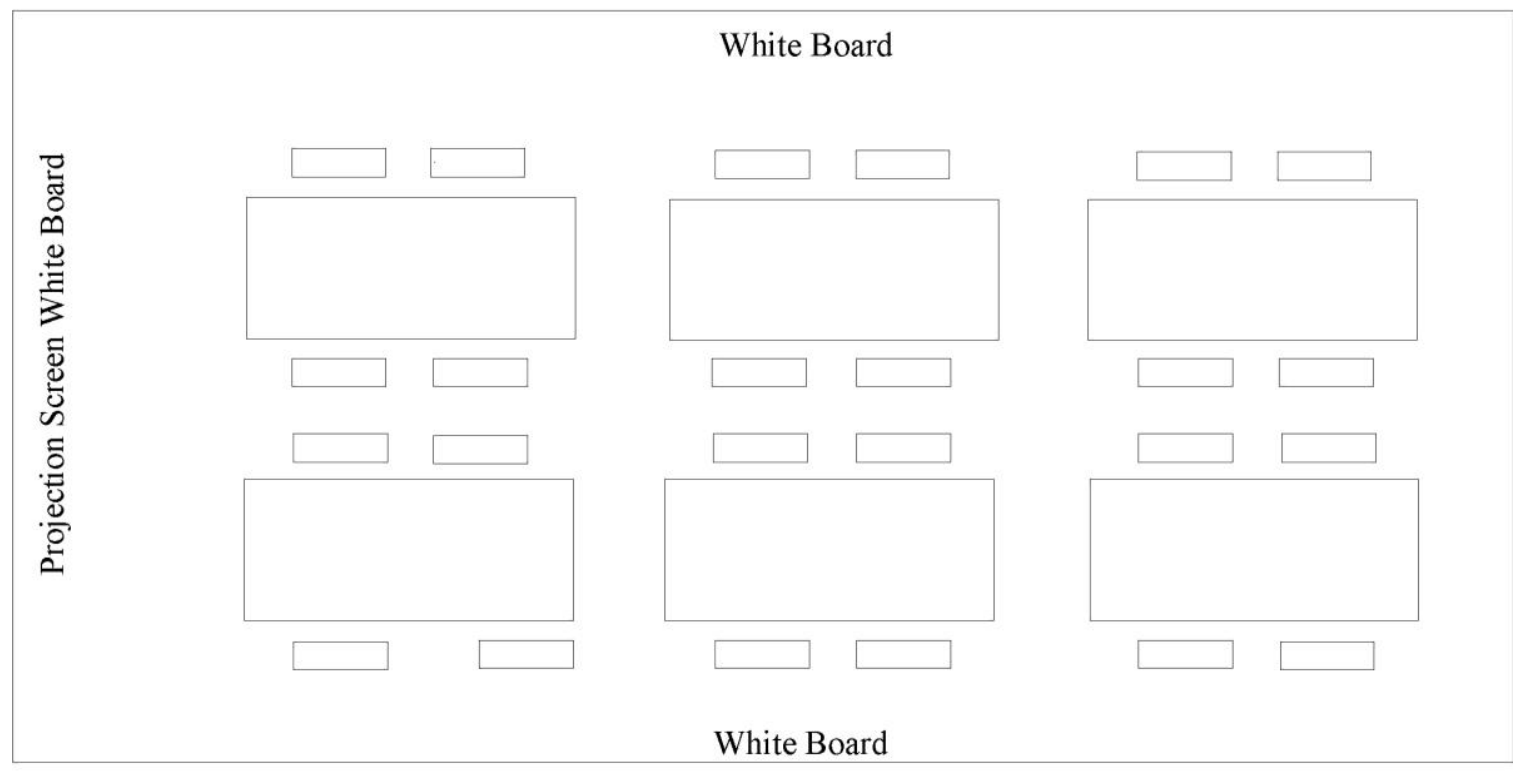

Figure 1. Spatial design of studio classrooms, (A) the Node classroom.

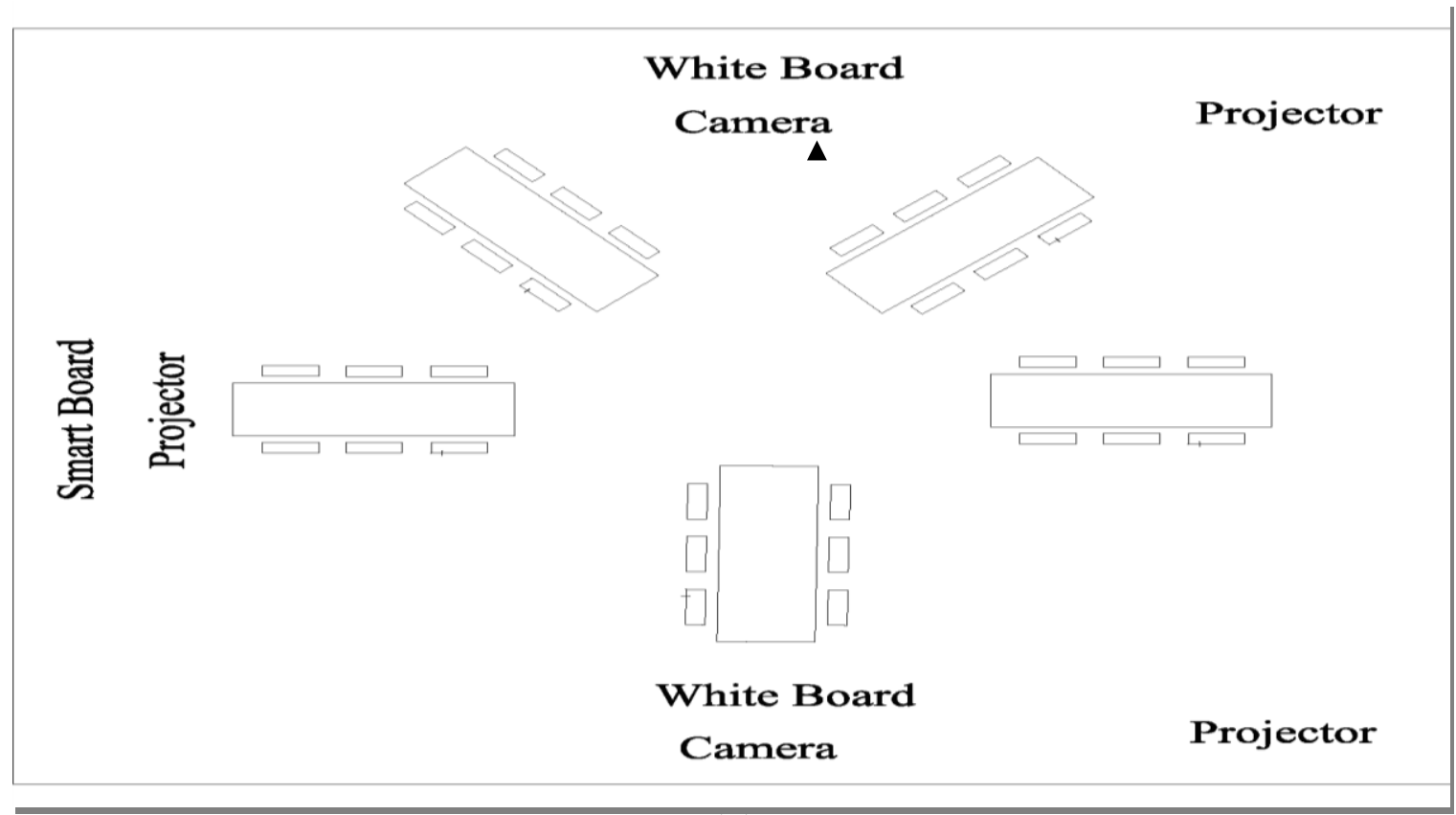

Figure 1. Spatial design of studio classrooms, (B) the Steelcase Spoke classroom.

The research participants were the 21 students and the instructor of a cooperative-learning course. Activities include small and large group projects, laboratory experiments, discussions, and debates. Apart from occasional presentations by the instructor, most group projects and laboratory experiments are guided-inquiry activities.

Procedure: We studied the impact of setting on student and instructor attitude and behavior. We did not investigate the impact of learning space design on 
performance. Since the same study group worked in both study spaces, some factors that are not usually controlled; teaching style, student motivation, and interpersonal environment; were accounted for, but confounding factors not normally encountered had to be considered. These included such factors as mix of learning activity and instructional technique used. Every precaution was taken to ensure that a comparable mix of learning activities was used in both rooms. A record was kept of daily class activities. The record was used to design subsequent class sessions with a uniform format in mind.

Various quantitative and qualitative tools were used in our investigation. The approach has been used before (Wong and Fraser, 1996, Dopplet and Schunn, 2008). A trained observer attended every 50-minute class session and recorded detailed observations of instructor and student activity and behavior in the classroom. The observer's notes were used to construct a record of the lesson plan and the instructional materials used, as well. The observer's rubric for observing learning environment, completed during each class session, is given in Table 1.

Table 1: Observer's classroom behavior rubric: The observer recorded the frequency with which the behaviors and activities as prompted by the rubric were noted during each class period.

1. Was active participation encouraged?

2. Were students encouraged to generate conjectures, alternatives solutions strategies, and ways of interpreting evidence?

3. Did the instructor act as a resource person, working to support and enhance student investigations?

4. Were students involved in the communication of their ideas to others using a variety of means and media?

5. Did the instructor's questions trigger divergent modes of thinking?

6. Was there active student communication, and did a significant amount of it occur between and among students?

7. Did student questions and comments often determine the focus and direction of classroom discourse?

8. Was there was a climate of respect for what others had to say?

9. Did students use a variety of means (models, drawings, graphs, concrete materials, etc.) to test phenomena?

10. Did students make predictions, estimations and/or hypotheses and devised means for testing them?

11. Were the students engaged in thought provoking activity that often involved critical assessment or thinking?

12. Did students reflected about their learning in class?

13. Were intellectual rigor, constructive criticism, and the challenging of ideas valued?

14. Did instructional strategies and activities respect students' prior knowledge and the preconceptions inherent therein?

15. Was the lesson designed to engage students as members of a learning community?

16. In this lesson, did student exploration precede formal presentation? 
17. In this lesson, were students encouraged to seek and value alternative modes of investigation or of problem solving?

18. Did the instructor listen to the student's problems?

19. Did the instructor pay attention to the students in the class?

20. Did the instructor explain the work to be performed?

21. Did the instructor appear polite?

22. Did the instructor appear helpful?

23. Did the instructor appear friendly?

Detailed observation of classroom tasks and behavior was augmented by two surveys of student perception and attitude followed by focused student interviews. Students were asked to complete the brief survey shown in Table 2 after each of eight class sessions. The class survey schedule and activity list is given in Table 3. At the conclusion of the course, the students were asked to complete the extensive survey shown in Table 4. The students submitted their responses anonymously to the project observer and not directly to the instructor. The observer's records and the survey results were not released to the instructor until the semester was concluded.

Table 2: Daily Questionnaire of Student Satisfaction: Students were asked to assess their learning environment in the Node classroom and in the Spoke classroom during sessions when class activities were comparable in both spaces.

1. The classroom encouraged the professor to teach better.

2. The classroom encouraged student participation.

3. Being in this classroom was a motivating factor.

4. Being in this classroom was a hindering factor for learning.

$1=$ substantially agree, $2=$ agree, $3=$ disagree, or $4=$ substantially disagree.

Table 3: Classroom activity and assessment schedule for class periods in which the student satisfaction survey was administered.

\begin{tabular}{|l|l|}
\hline Date/Location & Class Schedule \\
\hline $\begin{array}{l}\text { 20 January/ Node } \\
\text { classroom }\end{array}$ & $\begin{array}{l}\text { Risk Assessment group project } \\
\text { Matter Classification, Periodic Table Introduction } \\
\text { Molecular Formulas group project }\end{array}$ \\
\hline $\begin{array}{l}\text { 22 January/ Spoke } \\
\text { classroom }\end{array}$ & $\begin{array}{l}\text { Periodic Table Roadmap } \\
\text { Chemical Reactions } \\
\text { Chemical Equations Group Project } \\
\text { Balancing Combustion Reaction Equations }\end{array}$ \\
\hline $\begin{array}{l}\text { 27 January/ Node } \\
\text { classroom }\end{array}$ & Spectrometer Construction and Calibration Lab \\
\hline $\begin{array}{l}\text { 29 January/ Spoke } \\
\text { classroom }\end{array}$ & Atomic Spectra Measurement Lab \\
\hline $\begin{array}{l}17 \text { March/ Node } \\
\text { classroom }\end{array}$ & Fuel Value Lab \\
\hline 19 March/ Spoke & Fuel Value Results Discussion \\
\hline
\end{tabular}




\begin{tabular}{|l|l|}
\hline classroom & \\
\hline $\begin{array}{l}\text { March/Node } \\
\text { classroom }\end{array}$ & $\begin{array}{l}\text { Physical Properties of Water } \\
\text { Water and Life group Project }\end{array}$ \\
\hline $\begin{array}{l}2 \quad \text { April/ Spoke } \\
\text { classroom }\end{array}$ & Solubility and Conductivity Lab \\
\hline
\end{tabular}

Table 4: End-of-semester survey of student attitude and satisfaction. The responses are given on a five point scale with $1=$ excellent and $5=$ terrible. Some of the questions, along with the response means and standard deviations, maximum response value, and minimum response value are shown. An average response of less than 2.5 indicates a positive general attitude, while an average response of more than 2.5 indicates a negative general attitude.

\begin{tabular}{|l|l|}
\hline Question & $\begin{array}{l}\text { Response average } \\
\text { standard deviation, max, } \\
\text { and min. response. }\end{array}$ \\
\hline Effectiveness of Educational Activities & $2.18 \pm 0.53,3,1$ \\
\hline $\begin{array}{l}\text { 1. What overall rating do you give to the educational } \\
\text { activities in the Node classroom? }\end{array}$ & $2.47 \pm 1.01,5,1$ \\
\hline $\begin{array}{l}\text { 2. How enjoyable did you find the educational activities } \\
\text { in the Node classroom? }\end{array}$ & $3.47 \pm 1.12,5,1$ \\
\hline $\begin{array}{l}\text { 3. Given your current state of knowledge, estimate how } \\
\text { relevant the educational activities in the Node classroom } \\
\text { are to your future career. }\end{array}$ & $2.41 \pm 1.23,5,1$ \\
\hline $\begin{array}{l}\text { 4. The educational activities in the Node classroom had } \\
\text { many unique or special moments. }\end{array}$ & $3.12 \pm 0.86,5,2$ \\
\hline $\begin{array}{l}\text { 5. The educational activities in the Node classroom had } \\
\text { special meaning to me. }\end{array}$ & $2.41 \pm 1.06,5,1$ \\
\hline $\begin{array}{l}\text { 6. The educational activities in the Node classroom were } \\
\text { as good as expected. }\end{array}$ & $3.18 \pm 1.13,5,1$ \\
\hline $\begin{array}{l}\text { 7. The educational activities in the Node classroom were } \\
\text { satisfying to me. }\end{array}$ & $2.76 \pm 1.15,5,1$ \\
\hline $\begin{array}{l}\text { 8. The educational activities in the Node classroom stand } \\
\text { out as one of my best learning experiences. }\end{array}$ & $3.35 \pm 1.27,5,1$ \\
\hline $\begin{array}{l}\text { 9. The educational activities in the Node classroom were } \\
\text { worth the effort. }\end{array}$ & $2.53 \pm 1.07,5,1$ \\
\hline $\begin{array}{l}\text { 10. What overall rating do you give to the educational } \\
\text { activities in the Spoke classroom? }\end{array}$ & $2.35 \pm 1.11,5,1$ \\
\hline $\begin{array}{l}\text { 11. How enjoyable did you find the educational activities } \\
\text { in the Spoke classroom? }\end{array}$ & $2.24 \pm 0.90,5,1$ \\
\hline $\begin{array}{l}\text { 12. Given your current state of knowledge, estimate how } \\
\text { relevant the educational activities in the } \\
\text { classroom are to your future career. }\end{array}$ & $2.18 \pm 1.13,5,1$ \\
\hline $\begin{array}{l}\text { 13. The activities in the Spoke classroom had many } \\
\text { unique or special moments. }\end{array}$ & $3.06 \pm 0.90,5,2$ \\
\hline $\begin{array}{l}\text { 14. The educational activities in the Spoke classroom had } \\
\text { special meaning to me. }\end{array}$ & 2.50 . \\
\hline
\end{tabular}




\begin{tabular}{|c|c|}
\hline $\begin{array}{l}\text { 15. The educational activities in the Spoke classroom } \\
\text { were as good as expected. }\end{array}$ & $2.24 \pm 1.03,5,1$ \\
\hline $\begin{array}{l}\text { 16. The educational activities in the Spoke classroom } \\
\text { were satisfying to me. }\end{array}$ & $2.59 \pm 1.23,5,1$ \\
\hline $\begin{array}{l}\text { 17. The educational activities in the Spoke classroom } \\
\text { stand out as one of my best learning experiences. }\end{array}$ & $3.12 \pm 1.11,5,1$ \\
\hline $\begin{array}{l}\text { 18. The educational activities in the Spoke classroom } \\
\text { were worth the effort. }\end{array}$ & $2.29 \pm 1.16,5,1$ \\
\hline $\begin{array}{l}\text { 19. Being in the Spoke classroom was a motivating } \\
\text { factor. }\end{array}$ & $2.41 \pm 1.28,5,1$ \\
\hline $\begin{array}{l}\text { 20. Being in the Spoke classroom was a hindering factor } \\
\text { for learning. }\end{array}$ & $3.65 \pm 1.37,5,1$ \\
\hline 21. Being in the Node classroom was a motivating factor. & $2.71 \pm 1.10,5,1$ \\
\hline $\begin{array}{l}\text { 22. Being in the Node classroom was a hindering factor } \\
\text { for learning. }\end{array}$ & $3.65 \pm 1.37,5,1$ \\
\hline \multicolumn{2}{|l|}{ Technology } \\
\hline $\begin{array}{l}\text { 23. The use of technology in the Spoke classroom } \\
\text { contributed to my learning. }\end{array}$ & $2.41 \pm 1.18,5,1$ \\
\hline $\begin{array}{l}\text { 24. Overall, the quality of the technology used in the } \\
\text { Spoke classroom was: }\end{array}$ & $2.12 \pm 0.70,3,1$ \\
\hline $\begin{array}{l}\text { 25. The use of technology in the Node classroom } \\
\text { contributed to my learning. }\end{array}$ & $2.41 \pm 1.00,5,1$ \\
\hline $\begin{array}{l}\text { 26. Overall, the quality of the technology used in the } \\
\text { Node classroom was: }\end{array}$ & $2.59 \pm 0.94,4,1$ \\
\hline \multicolumn{2}{|l|}{ Educational Material Used } \\
\hline $\begin{array}{l}\text { 27. The recommended reading contributed to a better } \\
\text { understanding. }\end{array}$ & $1.71 \pm 1.05,5,1$ \\
\hline $\begin{array}{l}\text { 28. The educational material used provided excellent } \\
\text { support for learning. }\end{array}$ & $1.88 \pm 0.86,4,1$ \\
\hline $\begin{array}{l}29 \text {. The educational activity was excellently supported } \\
\text { by presentation aids. }\end{array}$ & $2.06 \pm 0.90,4,1$ \\
\hline \multicolumn{2}{|l|}{ Empathy } \\
\hline 30. The instructor listened to problems. & $1.59 \pm 0.62,3,1$ \\
\hline $\begin{array}{l}\text { 31. The instructor did not pay enough attention to the } \\
\text { class. }\end{array}$ & $4.18 \pm 1.01,5,1$ \\
\hline 32. The instructor explained the work to be performed. & $1.71 \pm 0.59,3,1$ \\
\hline 33. The instructor was polite. & $1.18 \pm 0.39,2,1$ \\
\hline 34. The instructor was helpful. & $1.35 \pm 0.49,2,1$ \\
\hline 35. The instructor was friendly. & $1.12 \pm 0.33,2,1$ \\
\hline \multicolumn{2}{|l|}{ Interaction Design } \\
\hline $\begin{array}{l}\text { 36. The importance of key aspects was appropriately } \\
\text { emphasized. }\end{array}$ & $1.82 \pm 0.73,3,1$ \\
\hline $\begin{array}{l}\text { 37. The quality of feedback to student comments was } \\
\text { excellent. }\end{array}$ & $2.06 \pm 0.75,3,1$ \\
\hline $\begin{array}{l}\text { 38. The interaction among participants was too } \\
\text { thoroughly planned in advance. }\end{array}$ & $3.18 \pm 1.13,5,1$ \\
\hline
\end{tabular}


Student perception of the learning environment can influence how a student learns as much or more than the context itself (Entwistle,1991). Previous studies of pupils' perceptions of their learning environment used questionnaires to assess classroom characteristics such as cohesiveness, satisfaction, competitiveness, diversity, goal direction, formality, disorganization, and democracy (Ellett et al., 1997; Fraser 1998; Fraser et al. 1995; Henderson et al. 2000).

A focus session with the students was conducted by a trained staff member to further explore issues raised by the end-of-semester survey.

The instructor's perception and attitude were recorded, also. The instructor kept a personal record of impressions of class activities and behavior which was compared with the other data at the conclusion of the semester.

\section{Results}

Observations of classroom activity: The observer's responses to the rubric given in Table 2 were tabulated and analyzed to determine how much class time was spent engaged in various learning activities. The observer's comments reveal the following. Some behaviors were most commonly observed in the spoke classroom. Overall, the spoke classroom was the dominant environment for active student participation in class-wide group work. The students were challenged with debate, discussion, and labs nearly every day in the spoke classroom. Generally, the instructor challenged the entire class with his questions more in the spoke classroom than in the node classroom. Discussion in the node classroom most often involved the instructor interacting with small groups of students.

Students made predictions, estimations and/or hypotheses and devised means for testing them most often in the spoke classroom. Usually, the instructor would introduce a new topic in the node classroom, and on the following class period in the spoke classroom, the students would conduct an experiment about that lesson. The instructional strategies and activities respected students' prior knowledge and the preconceptions inherent therein more consistently in the spoke classroom, because the spoke classroom was usually the place where students were assessed. On the other hand, students were also engaged as members of a learning community in the node classroom, since this is where the instructor presented new topics most often and small-group projects most often were undertaken.

Any lecture activity given in the spoke classroom was more intensive and example oriented than in the node classroom. For the most part, students were encouraged to generate conjectures, alternatives, solutions, strategies, and ways of interpreting evidence in both rooms an equal amount of time. However, the spoke classroom was a more rigorous place to interpret evidence given the work performed in that room.

Students were consistently involved in the communication of their ideas to others using a variety of means and media, depending on the types of classroom 
activity. They were regularly encouraged to seek and value alternative modes of investigation and of problem solving. Intellectual rigor, constructive criticism, and the challenging of ideas seemed valued depending on activity but regardless of setting.

Some behaviors were not dependent on classroom. The students communicated at least every day amongst themselves, irrespective of which room they were in. Student questions and comments often determined the focus and direction of classroom discourse regardless of classroom setting. Students were observed to reflect about their learning similarly in each classroom.

Students used a variety of means (models, drawings, graphs, concrete materials, etc.) to test phenomena in both rooms, although there was a slight preference for the Spoke classroom. The use of a variety of materials is not surprising in a chemistry course, and the preference for the Spoke classroom may not be significant.

Student attitude survey: A survey was given to assess student attitudes after each of eight separate class periods, four in the node classroom paired with four in the Spoke classroom. Four sessions were held toward the beginning of the semester, and four were held near the end of the semester as shown in Table 3. The type and duration of activity performed; group project, lab experiment, class discussion, and lecture; were approximately the same in both rooms.

The survey questions are given in Table 2. The response analysis is shown in Figure 2. The response trends in Figure 2 are compiled in two categories, agreement or disagreement with the survey statements of Table 2. The absolute magnitude of response depended on student attendance and differed for each session.

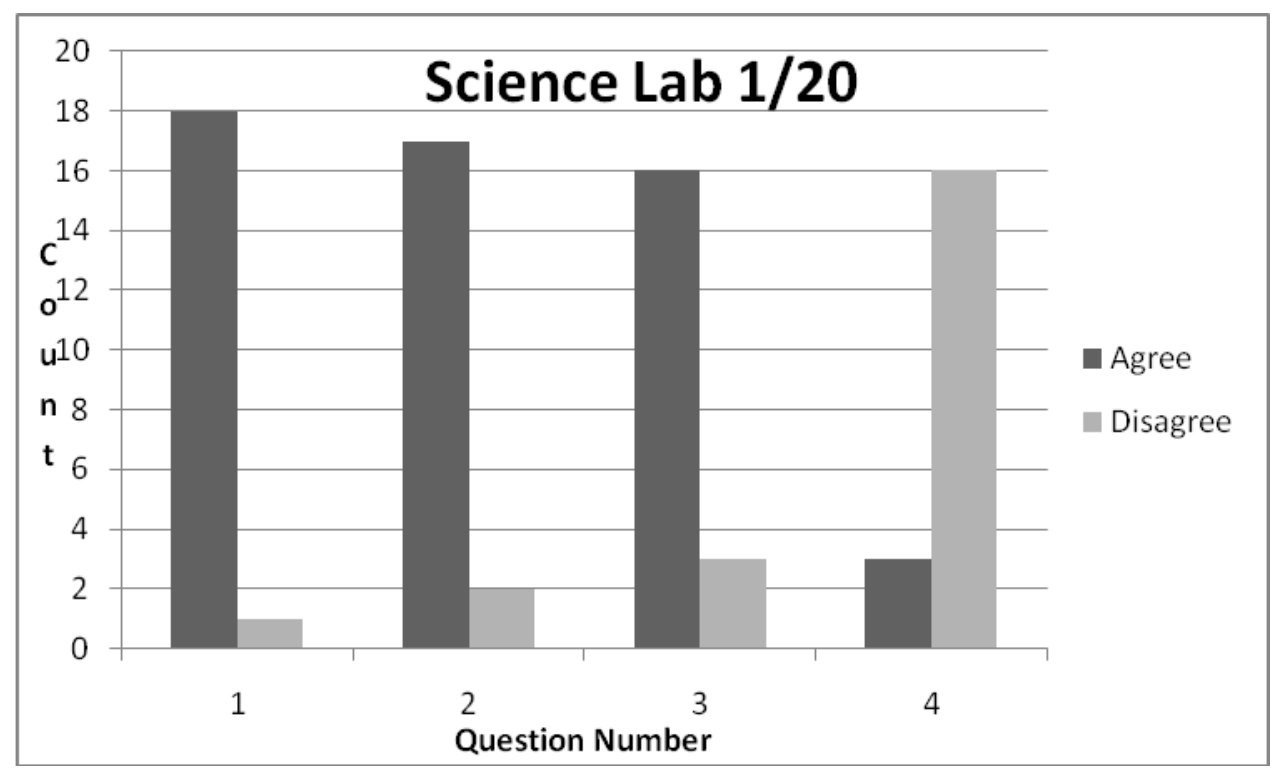



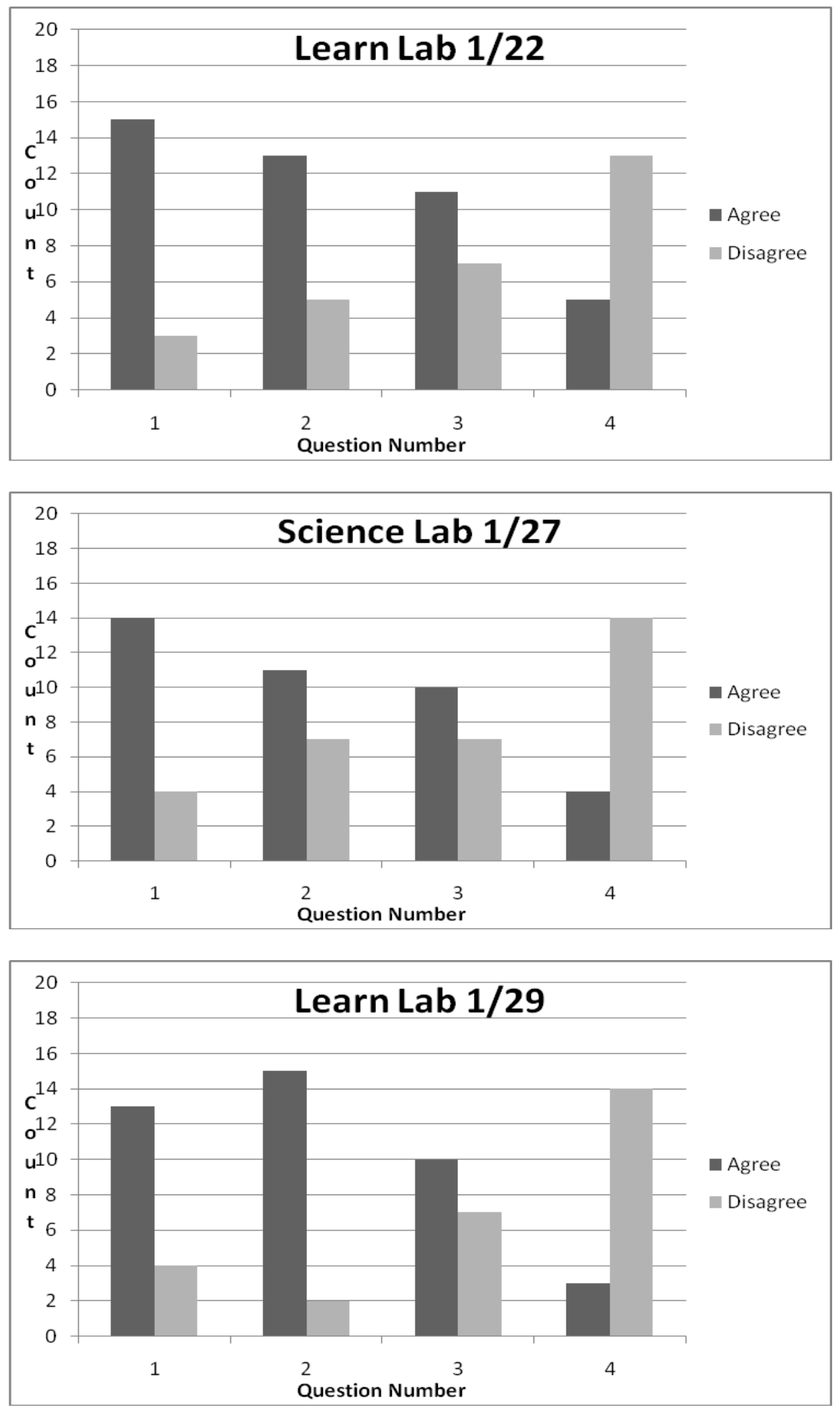

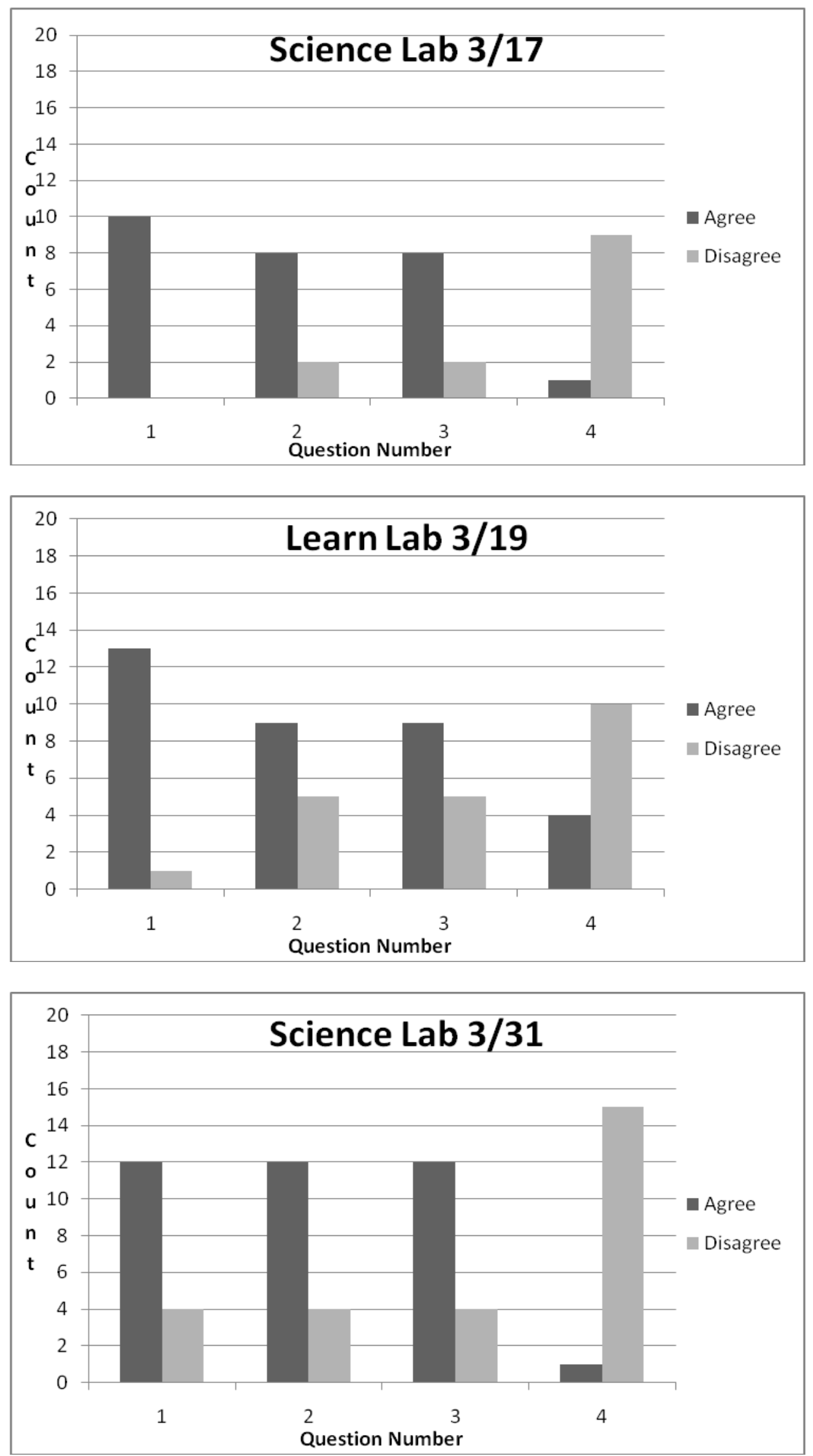


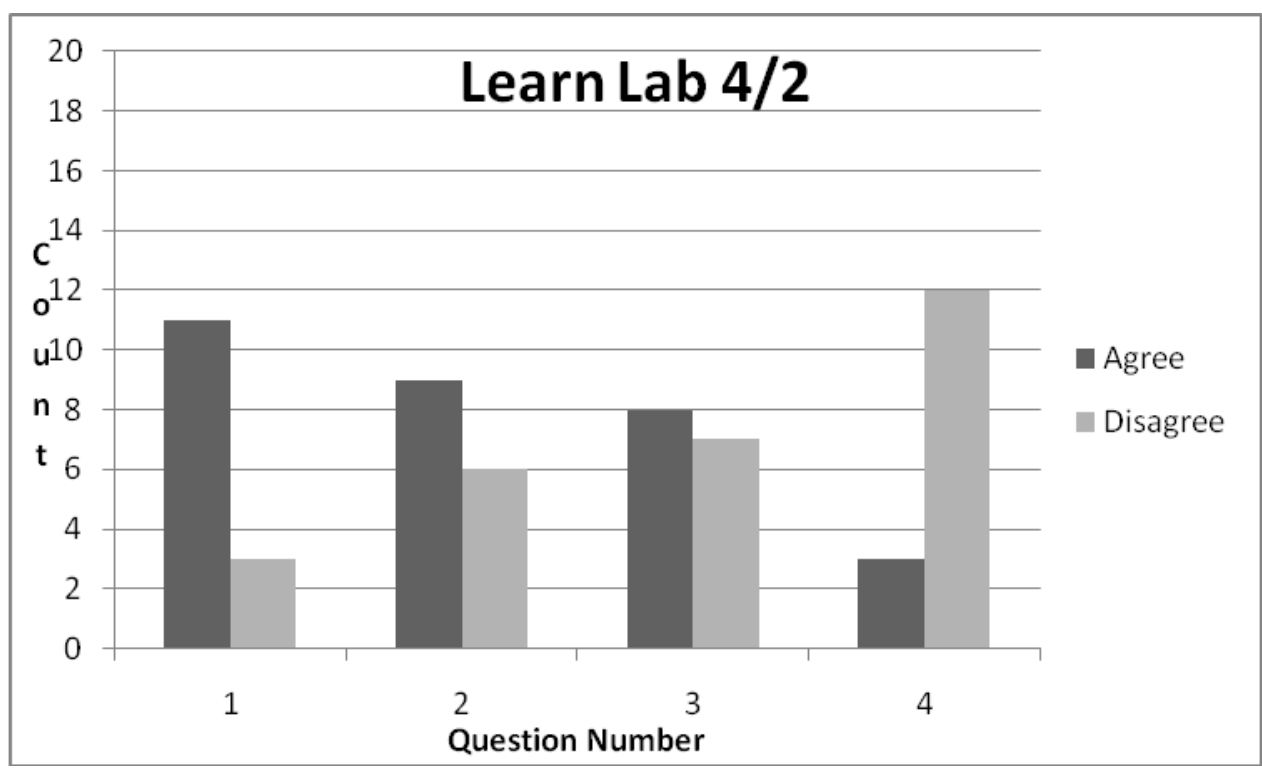

Figure 2: Responses to the daily questionnaire of student attitudes. The number of students agreeing or disagreeing with each of the four questions listed in Table 2 is given.

On the first survey session (2/20), 18 out of 19 students present showed satisfaction with the classroom, the Node classroom, agreeing with the first three statements and disagreeing with the fourth. On the following survey session $(2 / 22), 15$ of 18 students present expressed their satisfaction with the classroom, the Spoke classroom. On the third and fourth survey day (2/27 and 2/29), student satisfaction with the Node classroom had dropped significantly, but student participation was perceived to have improved in the Spoke classroom. A pair of spectroscopy labs were performed on 2/27 and 2/29 which appear to have been more engaging than the combustion labs performed later on $3 / 17$ and 3/19 during which the students expressed the least satisfaction. Student satisfaction with the Node classroom rebounded on 3/31. Class activities included group projects and discussion similar to that on $2 / 20$. Satisfaction with the Spoke classroom remained at the lowest level on $4 / 2$ during which a difficult inquiry experiment was performed. The same general trend was observed for all four of the survey questions, although trends of responses given by specific individual participants differed substantially from one another.

The highly positive response given in the first survey was probably influenced by factors other than the physical classroom environment. The student's initial attitudes may have been influenced by a generally positive response to the novelty of participating in a research study (Hawthorne effect). At the time of the first survey, the course was already three weeks old, so response to a novel learning environment was not likely. Students may have been responding to their enjoyment of the activity.

Throughout the study, almost all of the students agreed that either the Node classroom or the Spoke classroom encouraged the professor to teach better, 
encouraged student participation, and was a motivating factor. In almost every survey, faculty teaching was regarded most highly, followed in order by student participation, and by student motivation. All disagreed that either classroom was a hindering factor for learning. There was substantial disagreement between individual participants over which of the two learning spaces was best, however. Student disagreement was greatest in the Spoke classroom.

End-of-Semester Student Attitude Survey: The end-of-semester survey consisted of 63 questions that explored student perception of the effectiveness of the educational activities, the classroom technology, and the educational materials used. The instructor's empathy towards students, the student's interaction with the instructor, the instructor's teaching skills, the student's learning style, the student's engagement with science, the student's involvement with education in general, and the student's engagement with technology were explored, also. Half of the questions explored the psychosocial environment of the two classrooms. The data was examined for evidence of such aspects as student involvement, cooperation and task orientation as well as group cohesiveness.

Some survey questions along with the response means, standard deviations, maximums, and minimums are shown in Table 4. Response choices are given on a five-point scale, 1 signifying a very positive attitude and 5 signifying a very negative attitude. An average response of less than 2.5 indicates a positive general attitude, while an average response of more than 2.5 indicates a negative general attitude.

Responses to Questions 40 - 43 indicate that, at the conclusion of the semester, student attitudes were positive toward both classrooms, on average, with the most favorable bias exhibited towards the Spoke classroom. Question 1, an overall rating of classroom activities, was the only question in which a positive bias was shown toward the Node classroom. Responses to Questions 24 and 26 showed student appreciation of the technology in the Spoke classroom, in particular. The individual response results were not uniform, however. Some participants exhibited a decidedly positive attitude while some students exhibited a clear negative attitude toward one or the other teaching space.

The positive responses to Questions 27 - 48 indicate a healthy and productive learning environment; however responses to Questions 3, 5, 8, 12, 14, and 17 indicate a slightly negative attitude toward the course itself. While many factors may be responsible for this result, one stands out. All study participants were non-science majors taking a required science course. When asked at the beginning of the semester, most participants reported a negative attitude towards science, confirmed in the learner profile questions 49,52 , and 53 , and some participants reported negative experiences with their prior science education. The students showed little interest in technology, in general. Nevertheless, the students asserted a strong involvement with education in general. 
Students view the two learning environments as characterized by good student cohesiveness, involvement, task orientation, and cooperation. Most students stated that they enjoyed working in groups. Taken together, results reveal a positive learning environment regardless of classroom.

Student Focus Group Results: A focus group was held at the end of the semester. In order to obtain information on student perceptions of learning in various physical environments, the participants were prompted with two questions to describe their experience in the two study spaces as well as in conventional classrooms.

The participants disagreed among themselves as to which classroom produced the most positive experience. While one participant stated a preference for the Spoke classroom, another preferred the Node classroom, both claiming it easiest to concentrate on work in the preferred teaching space. For example, one student explained that the technology in the Spoke classroom enabled her to stay abreast of class activities; the other claimed that the Spoke classroom technology was distracting.

Several students mentioned that the Spoke classroom technology contributed significantly to positive learning experiences. The students went on to mention that the multiple projection screens improved visibility and made it easier to take notes no matter where they sat. There is no lecture stage in the Spoke classroom, and it wasn't always easy to determine what visual material the instructor was referring to. The interactive screen technology made it easier to follow the instructor's presentations. The whiteboard camera's ability to post information to the web helped students to revisit notes made by the instructor during lectures. The huddle boards helped with organizing and reporting group projects without having to make copies of the work product.

Several students noted that the Node classroom and the Spoke classroom promoted different types of group activity. The Node classroom best supported small group projects as opposed to case studies and other large group activities favored in the Spoke classroom. Group isolation and social pressure to do the work were mentioned as factors in the Node classroom, while good communication with the other participants and comfort was perceived to be best in the Spoke classroom. One student noted that the Node classroom was best because he felt forced to engage in group work, adding that group work was the most effective way to learn.

Summarizing the focus discussion, both classroom spaces were characterized as supporting cooperative groups of students who interacted freely during class periods. The Node classroom was good for small group projects, while the Spoke classroom offered the best sight lines and was better for having class-wide discussions and for viewing material on the projection screens. "Comparatively, I think I had a better learning experience in the Spoke classroom because of the smaller space and the new technology, however I liked both of the classroom 
spaces because they were new and colorful." "The Node classroom was more traditional, with the students in one section of the classroom all facing the front where the professor was, so it was more subdued during lectures in that class. The Spoke classroom allowed more movement for the professor, and it gave students more leeway with the position they were sitting in, leading to a freer exchange of ideas and conversations during discussions and lectures."

Instructor's Comments: In order to help characterize the learning environment from the participant's perspective, record was kept of the instructor's attitudes and behavior as influenced by classroom design. The instructor's observations of student behavior were recorded, also. The Node classroom was found to be a pleasant space in which to work because it is spacious and filled with bright, natural light. Site lines were not uniformly good, however.

The front of the Node classroom proved most attractive to the instructor, since about $30 \%$ of the classroom space is devoted to resources that support lecturing, and most resources were grouped there. Group presentations were made almost exclusively from the front of the room, also. The student groups recorded their work on the classroom's white boards, but no facility was available to preserve their work. Half of the students in the class had their backs to each other. The seating arrangement promoted small-group, active-learning methods such as "Physics by Inquiry" (Laws, 1991) and "Process-Oriented, Guided-Inquiry Learning, POGIL" (Spencer and Moog, 2008), but it inhibited interaction between groups. When needed, it was necessary to make special arrangements in order to encourage cross-group, class-wide interaction.

The instructor found the Spoke classroom oppressive as there was not as much window space, and the projection screens required subdued lighting. Also, the space felt somewhat cramped compared to the Node classroom. Since there was no good place to stand in the room, it was most comfortable to move about the room interacting with students and working at the white boards. It was extremely convenient to photograph and post work on the white boards and on the group huddle boards, and this resource was regularly used. The site lines in the room were very good. The students could easily see the work presented on the white boards as well as each other. The seating arrangement encouraged interaction between groups during class discussions and debate, and no special effort was needed to encourage this behavior. The facilities made it easy for student groups to make presentations from their post.

\section{Discussion}

The results show that a healthy learning environment existed in both teaching spaces. Students found both the Node classroom and the Steelcase Spoke classroom more satisfying to work in than normal classrooms designed for lecture presentations. This is in agreement with earlier studies comparing rooms designed for active learning with conventional lecture rooms. (Brooks, 2011; Muthyala, and Wei Wei, 2013 ) Students commented on the enhanced social interaction which promoted group cohesiveness, involvement, task orientation, 
and cooperation. Several mentioned that, unlike their experience in conventional classrooms, they got to know their classmates. Several students recognized that they were highly focused on the task of listening to the instructor in the conventional classroom. Some mentioned the efficiency of "learning by doing" in a studio classroom. Behavioral patterns of this sort were reported in studies of student performance in K-12 classrooms.

The Spoke classroom favors and is clearly preferred for class-wide, group activities such as case studies, discussions, and debates. The seating provides excellent sight lines, enabling everyone in the class to easily see visual presentations and interact with everyone else. The sight lines in the Node classroom are not as good as in the Spoke classroom. The instructor and students found it more difficult to see each other there. In prior studies, students identified good sight lines as one important factor having positive impacts on learning (Veltri, Banning, and Davies, 2006).

The Node classroom does not readily support large class-wide projects. This is a good environment for small-group, guided-inquiry methods such as "Physics by Inquiry" and "Process-Oriented, Guided-Inquiry Learning, POGIL". The seating arrangement focuses attention on the group, reducing distractions that occur outside the group. Interaction between groups was minimized. When needed, interaction between groups had to be encouraged with special measures. For example, a spy was occasionally designated in each study group to monitor the activities of other groups.

Student interaction with the instructor and with other students depends upon the ability to have face-to-face contact (Steinzor, 1950; Hare and Bales, 1963; Gump, 1987; Rosenfield, Lambert and Black, 1985). The Node classroom and the Spoke classroom are approximately the same size, and distance between students does not differ significantly between the two classrooms. So, distance between students was not a probable factor in the differing ability of the two classrooms to enable various group activities. The results do indicate that simply adjusting the angle between chairs affects the degree of interaction between students and in itself enables or constrains different group activities. This possibility was suggested in earlier research (Argyle, 1975).

The nature of the academic task and type of behavior desired should dictate the seating arrangement (Wannarka and Ruhl, 2008). The seating arrangements in the two classrooms are alterable, and in the event of compelling need, the rooms can be rearranged to maximize their utility for each class activity. This is most easily done in the Node classroom. This is not as convenient in the Spoke classroom due to the physical arrangement of the audio-visual facilities there. However, rearranging the seating is not without problems. It takes time, and it introduces confusion to the proceedings.

Although the Node classroom has many of the same technology enhancements, they are not as well integrated. The visual aids and the seating did not always work well together because of poor sight lines. Although student groups could 
use white boards to present their work, there was no convenient way to preserve it for future use. While the resources in the Spoke classroom could be used simultaneously for various purposes, this was not possible in the Node classroom.

\section{Acknowledgement}

This research was supported, in part, by a grant from the Center for Scholarly and Creative Excellence of Grand Valley State University.

\section{References}

Acker, R and Miller, M (2005). "Campus Learning Spaces: Investing in How Students Learn", Educause Centre for Applied Research, ECAR Research Bulletin, Vol 2005(8).

AMA Alexi Marmot Associates (2006). "Spaces for learning. A review of learning spaces in further and higher education.", A report for the Scottish Funding Council prepared by AMA Alexi Marmot Associates in association with HAA design.

Argyle, M (1975). Bodily Communication. Methuen, London.

Banning, J.H. (1992). "The connection between learning and the learning environment", Children,. Learning \& School Design, The First National Invitational Conference for Architects and Educators, p.24

Brase, W. (1988). "Design criteria for effective classrooms", Planning for Higher Education, 17(1), 81-91.

Brooks, D.C. (2011). Space matters. The impact of formal learning environments on student learning. J. Educ. Technol., 42, 719-726.

Brooks, D.C. (2012). Space and Consequences: The Impact of Different Formal Learning Spaces on Instructor and Student Behavior. J. Learning Spaces, 1 (2).

Brown, B. and Lippincott, J. (2003). "Learning spaces: more than meets the eye", Educause Quarterly No. 1, 14-16.

Cannon, R. A. (1988). "Learning Environment" in D. Unwin and R. McAleese (Eds.), Encyclopedia of Educational Media Communications and Technology, Greenwood Press, New York, 222-235.

Conway, K. (1993). "Master Classrooms: Classroom Design with Technology in Mind", Resources in Education, http://www.iat.unc.edu/publications/conway/conway1.html.

Cruickshank, W.M. and Quay, H.C. (1970). "Learning and physical environment: The necessity for research and research design", Exceptional Children, 37, 261-268.

Dopplet, Y., and Barack, M. (2002).Pupils identify key aspects and outcomes of a technological learning environment. J. of Technological Studies, 28(1), 12-18.

Dopplet, Y. and Schunn, C. D. (2008). Identifying students' perceptions of the important classroom features affecting learning aspects of a designed-based learning environment. Learning Environ. Research, 11, 195-209.

Dori, Y. and Belcher, J. (2004). "How does technology-enabled active learning affect undergraduate students' understanding of electromagnetic concepts?", Journal of the Learning Sciences, 14(2), 243-279

Earthman, G. I., and Lemaster, L. (1996). Review of the research on the relationship between school buildings, student achievement, and student behavior. Report Number: EF005023, Council of Environmental Facility Planners International, Scottsdale, Arizona

Ellett, C. D., Loup, K. S., Culross, R. R., McMullen, J. H., and Rugutt, J. K. (1997). Assessing Enhancement of Learning, Personal Learning Environment, and Student Efficacy: Alternatives to Traditional Faculty Evaluation in Higher Education, Journal of Personnel Evaluation in Education, 11, 167-192. 
Entwistle, N. J. (1991). Approaches to learning and perceptions of the learning environment:, Introduction to the special issue. Higher Education, 22, 201-204.

Espey, M. (2008). "Does Space Matter? Classroom Design and Team-Based Learning", Review of Agricultural Economics, 30(4), 764-775.

Fisher, K. (2000). "Building Better Outcomes: The Impact of School Infrastructure on Student Outcomes and Behavior", Schooling Issues Digest.

Fraser, B. J., Giddings, J. G., and McRobbie, J. C. (1995). Evolution and validation form of an instrument for assessing node classroom environments. Journal of Research in Science Teaching, 32, 399-422.

Fraser, B. J. (1998). Science learning environments: Assessment, effects, and determinants. In Fraser, B. J., and Tobin, K. G., (Eds.) International Handbook of Science Education, Kluwer, Dordrecht, The Netherlands, pp 527-564.

Hare, A. P., and Bales, R. F. (1963). Seating position and small group interaction. Sociometry, 26, 480-486.

Henderson, D., Fisher, D., and Fraser, B. (2000). Interpersonal behavior, laboratory learning environments and student outcomes in senior biology classes. J. Research in Science Teaching, 32, 399-422.

Hill, M. C. and Epps, K. K. (2009). “Does Physical Classroom Environment Affect Student Performance, Student Satisfaction, and Student Evaluation of Teaching in the College Environment?", Proceedings of the Academy of Educational Leadership, 14(1), 15-19.

Hunley, S. and Schaller, M. (2009). "Assessment: The key to Creating Spaces that Promote Learning", Educause Review, 44(2), 26-34.

Hurst, M. D. (2005). "Schools eye future costs", Education Week, 24(35), 34-39.

Kroemer, K. and Grandjean, E. (1997). Fitting the Task to the Human: a textbook of occupational ergonomics, Fifth Edition, Taylor and Francis, London

Laws, P. 1991. "Workshop Physics: Learning Introductory Physics by Doing It." In D. DeZure, D. (Ed)., Learning from change, landmarks in teaching and learning in higher education, pp. 247-248.

Muthyala, Rajeev S., and Wei Wei, 2013. Does Space Matter? Impact of Classroom Space on Student Learning in an Organic-First Curriculum, J. Chemical Education, 2013, 90, 45-50.

Monahan, T. (2002). "Flexible Space and Built Pedagogy: Emerging IT Embodiments," Inventio, 4(1), 1-19.

Moore, G. T. (1986). "Effects of the Spatial Definition of Behavior Settings on Children's Behavior: A Quasi-Experimental Field Study", Journal of Environmental Psychology, 6, 205-231.

Oliver-Hoyo, M.T., Allen, D., Hunt,W.F., Hutson J., and Pitts, A. 2004. Effects of an active learning environment: Teaching innovations at a research I institution. J. Chem Educ., 81, 441-448.

Rosenfield, P., Lambert, N. M. and Black, A. (1985). Desk arrangement effects on pupil classroom behaviour. Journal of Educational Psychology, 77, 1, 101-108.

Sanoff, H. (1994). The School Building Assessment Manual. John Wiley \& Sons, New York.

Sanoff, H. (2000). Community Participation Methods in Design and Planning. John Wiley, \& Sons, New York.

Schneider, M. (2002). "Do school facilities affect academic outcomes?", National Clearing house for Educational Facilities, November 2002.

Scott-Weber, L., Marini, M., and Abraham, J. (2000). Higher education classrooms fail to meet needs of faculty and students, J. of Interior Design, 26(1), 16-34.

Sommer, R. and Olsen, H. (1980). “The soft classroom”, Environment and Behavior, 12 (1) 1 3-16.

Spencer, J. N., \& Moog, R. S., 2008. "The Process Oriented Guided Inquiry Learning Approach to Teaching Physical Chemistry". In M.D. Ellison \& T.A. Schoolcraft 
(Eds.), Advances in Teaching Physical Chemistry: ACS Symposium Series 973 (pp. 268-279). Washington, D.C.: American Chemical Society.

Strange, C. C., and Banning, J. H. (2001). Educating by Design : Creating Campus Learning Environments That Work, Jossey-Bass.

Steinzor, B (1950). "The spatial factor in face-to-face discussion groups", Journal of Abnormal and Social Psychology, 45, 552-555.

Syllabus Media Group (2005). "Designing the Space: A conversation with William J. Mitchell, Campus Technology", Syllabus Media Group, June 2003, www.campus- technology.com/article.

Tanner, C. K. (2000). "The Influence of School Architecture on Academic Achievement", Journal of Educational Administration, 38 (4), 309-330.

Tinto, V. (1997). Classrooms as communities: Exploring the educational character of student persistence. J. of Higher Education, 68(6), 599-623.

Veltri, S., Banning, J. H. and Davies, T. G. (2006). "The Community College Classroom Environment: Student Perceptions", College Student Journal, 40(3), 517-528.

Wannarka, R. and Ruhl, K. (2008). Seating arrangements that promote positive academic and behavioral outcomes: a review of empirical research. Support for Learning, 23 (2), 89-93.

Weinstein, C.S. (1979). "The Physical Environment of the School: A Review of the Research" Review of Educational Research, 49 (4), 577-610.

Wong, F. L. A., and Fraser, B. J. (1996). Environment attitude associations in the chemistry laboratory classroom. Research in Science and Technology Education, 14, 91-102.

Zandvleit, D. B. and Fraser, B. J. (2004). Learning Environments in Information and Communication Technology Classrooms, Technology, Pedagogy and Education, 13(1), 97-123. 